\title{
Students' Problems in Answering Reading Comprehension Question of Descriptive Text in The "Mandiri" Textbook Published by Erlangga at SMPN 1 Kepahiang
}

\author{
Meri Diana \\ Postgraduate Student of English Education Study Program, Bengkulu University, Indonesia \\ bengkulumeri017@gmail.com \\ Syahrial \\ Lecturer of Postgraduate of English Education Study Program, Bengkulu University, Indonesia \\ syahrial@unib.ac.id \\ Wisma Yunita \\ Lecturer of Postgraduate of English Education Study Program, Bengkulu University, Indonesia \\ wismayunita@unib.ac.id
}

\begin{abstract}
This research aimed to find out the students' problems in answering reading comprehension questions of descriptive text in the "Mandiri" textbook published and the causes of students' problems in answering reading comprehension questions of descriptive text in the "Mandiri" textbook published by Erlangga at SMPN 1 Kepahiang. The design of this research was a descriptive quantitative research. This research was designed based on the problems identified and arranged to adjust the main purpose of the research, so that the researcher employed descriptive method. The researcher took 50 students as the sample of this research. The instruments of this study were reading test and interview guideline. The researcher used a reading test in multiple choice forms consisted of fourty numbers of questions included in Mandiri textbook published by Erlangga. Another instrument was an interview guideline. The interview guideline was arranged based on the result of the reading test to reconfirm the result of the reading test and to get an indepth data on the causes of students' difficulties in reading comprehension. The findings of this research were; (1) the students' problems in answering reading comprehension questions of descriptive text in the "Mandiri" textbook published by Erlangga at SMPN 1 Kepahiang were finding main idea, identifying specific information, inference, and vocabulary; (2) there were four causes of students' problems in answering reading comprehension questions of descriptive text in the "Mandiri" textbook published by Erlangga at SMPN 1 Kepahiang; (a) finding main idea is rather complicated, the students need to read the text repeatly to find the main idea; (b) the students need to read from the beginning to finish this description so that they can get the information and answer the questions given; (c) to find inferences they must know the text well and clearly; (d) There are some words that they find difficult to understand and they have never met. They answered that there are some words which are not familiar to them.
\end{abstract}

Keywords: Reading, difficulties, Mandiri Textbook

\section{A. Introduction}

Reading is one of skills in English to make people getting information from what they read in order to be able to reach the comprehension. Reading is a fluent process of readers combining information from a text and their own background knowledge to build meaning. 
But some of people argue that reading some article or textbook is easy but reading with comprehension is more difficult. Actually, reading skill is very important for students such as; the students can get information from they read, the students can add their knowledge and can enlarge the way of their thinking by reading any text. So the students should have skill in reading to add their information and enrich their knowledge. Moreover, reading comprehension is the ability of the reader to recite the contents of the argumentation, expository, or read adescription of a particular topic (Wibowo et al, 2019; Martinal, et al. 2020; Dhillon, et al. 2020).

Reading is a process of decoding message which readers own experience and knowledge (Martina, et al. 2020; Adeani, et al. 2020; Febriani, et al. 2020). According to Nunan (2003), "Reading is a fluent process of readers combining information from a text and their own background knowledge to build meaning". Reading is an active process. The students should recognize the word, which are used by teacher, and also the students should be familiar with the grammar in the text. It means that reading is an activity which is tended to get information from the text, and reader should use a specific technique to understand the text is being read (Handayani, et al. 2020).

In addition, Nunan (2003) stated that there are eight principles of teaching reading, exploit the reader's background knowledge, build a strong vocabulary base, teach for comprehension, work on increasing reading rate, teach reading strategies, encourage students to transform strategies into skills, build assessment and evaluation into your teaching and strive for continuous improvement as a reading teacher. Those principles will help the teacher to teach reading in order to help students reach the main goal of reading. That is comprehension.

Comprehension is the goal of the reading. In reading comprehension, students not only read the text but also understand what they read. The brief opinion about reading is from Nuttal (2006) state that reading is an activity to understand the message from text and the reader read a text, in order to get information that is sent by the writer. It means that reading is not only to get some information and knowledge, but also to understand and look for the meaning wants to convey the writer.

One of the abilities that should be had by the students while reading is literacy. Literacy is the ability to read for the purpose of differentiately information from the written words (Yunita, 2012). In English, there are several kinds of the text for students to learn, namely: procedure, recount, narrative, description, news item, report, analytical exposition, 
spoof, hortatory exposition, explanation, discussion and review. It is important for the students to comprehend a reading text by having knowledge in general view of the text because it can help them to understand main idea of the text and predict what will be discussed on the text. Grabe (2002) defines reading as a complex ability to extract, build meaning from a text. In short, reading is generally defined as a process of identifying a written or printed text to understand its meaning. As a matter of fact, students find it hard to comprehend the texts in English. This indicates that students have their constraints in comprehending reading text.

Text types can be divided into two main types of text: literary and factual (Anderson and Anderson, 1998). Literary text is used to tell the readers about human experiences, usually in an imagination way. Its purpose is to make the readers and listeners think, laugh, and cry. The example of literary texts is narrative, dramatic, novel, song lyric and poem. Moreover, factual text presents information or idea. The purpose of this type is to inform, instruct, educate or persuade the reader or listener. The examples of factual text types are explanation, information report, discussion, exposition, recount, factual description, and procedure.

However, based on the result of final examination in SMPN 1 Kepahiang, it was found that most of the students got difficulties in understanding the questions of final examination which are related to reading text especially descriptive text. Twenty students said that they got difficulties in determining the main idea and some students said that they cannot find some inference questions in reading text. Moreover, a study by Mauli (2014) entitled An Analysis of Students' Problems in Finding Main Idea of Reading Text at The Second Grade of MTSN 1 Kotabumi found that there are six problems faced by students in finding main idea. The previous study conducted the research on students' problems in finding main idea of reading text. Moreover, to know what the difficulties or constraints that they faced in understanding the reading text in detail, the researcher needs to analyze the students' difficulties and the reading parts which cannot be understood by the students. Therefore, this present research aims to find out the students' reading comprehension problems to answer reading questions of descriptive text in SMPN 1 Kepahiang. The title of this research is An Analysis of the Students' Problems in Answering Reading Comprehension Questions of Descriptive Text in the "Mandiri" Textbook Published by Erlangga at SMPN 1 Kepahiang. 


\section{B. Research Methodology}

The design of this research was a descriptive quantitative research. This research was designed based on the problems identified and arranged to adjust the main purpose of the research, so that the researcher employed descriptive method. The population is the establishment of boundary condition that specify who shall be included in or excluded from the population. The population of this study was 150 students at seventh grade of SMPN 1 Kepahiang. The researcher determined the sample of this research based on the calculation of the sampling technique by using sample size calculator application. Therefore the researcher took 50 students as the sample of this research.

The instruments that were used to collect the data in this study were reading test and open ended questionnaire. Reading test is aimed to measure students' reading comprehension. The researcher used reading test in multiple choice forms which consisted of fourty numbers of questions included in Mandiri textbook published by Erlangga (see appendix 1). Another instrument was an open ended questionnnaire. The questionnaire was arranged based on the indicator to reconfirm the result of the reading test and to get a depth data about the causes of students' difficulties in reading comprehension. The instruments were validated by expert judgment and triangulation.

The data of this research were collected by following steps; (1) The researcher gave reading test based on the reading comprehension questions in Mandiri textbook. (2) The researcher identified the students' difficulties in understanding reading text by looking the correct and incorrect answers from the students. (3) The researcher analyzed what aspects of reading comprehension which become the students' difficulties in answering descriptive text questions. (4) The researcher concluded the dominant aspect which becomes the students' students' difficulties in answering descriptive text questions. (5) The researcher gave open ended questions to some students who get many difficulties in answering the questions. It was to reconfirm the result of reading test and to investigate the causes of the difficulties in answering the questions. The interview was done after the researcher analyze the reading test. The researcher used theory from Arikunto (2009) in taking the sample of interview. The researcher took the sample of open ended question from $40 \%$ of sample which were about 20 students. 


\section{Results and Discussion}

\section{Results}

The researcher got the data about the Students' Reading Comprehension and it was described into several points based on the test and open ended questions.

\section{Students' Problems in Answering Reading Test}

The reading test was given to the students in multiple choice form with total questions 40 items of descriptive text to find out the students' problems in answering reading test. The researcher divided the aspects of reading into four, they were; finding main idea, identifying specific information, inference, and vocabulary and reference.

There were fourty questions which answered by 50 students with the number of incorrect answers more than correct answers. It means that the students have problems in answering reading descriptive text questions. The result showed that mostly students cannot answer the questions correctly. There were only seven students who answered question number 1 correctly, 18 students for number 2, 26 students for question number 3, 4 students for question 4, 13 students for question 5, 25 students for question 6, 20 students for question 7, 21 students for question 21, and the rest of questions can be seen in the table above.

The result showed that the question 4 was dominantly answered incorrect by the students. The question was about finding the main idea. The students got problemin answering the question abot what the text mainly discuss. Then another much incorrect answer was the question number 22. Question 22 asked the students to find specific information in the text. Mostly the students answered incorrect answer for this question. Then, to know the problems of each aspect of reading, see table 1.

Table 1 Students' Reading Comprehension

\begin{tabular}{|c|c|c|c|c|}
\hline No & Aspect of Reading & Number of Question & $\begin{array}{l}\text { Correct } \\
\text { Answer }\end{array}$ & $\begin{array}{l}\text { Incorrect } \\
\text { Answer }\end{array}$ \\
\hline 1 & Finding main idea & $1,4,20$ & 41 & 109 \\
\hline 2 & $\begin{array}{l}\text { Finding specific } \\
\text { information }\end{array}$ & $\begin{array}{l}2,3,5,6,7,8,9,12,13,14 \\
16,17,18,19,22,23,24 \\
25,26,27,28,29,30,31\end{array}$ & 450 & 750 \\
\hline 3 & Inference & $10,15,21$ & 49 & 101 \\
\hline 4 & Reference/Vocabulary & $\begin{array}{l}11,32,33,34,35,36,37,38, \\
39,40\end{array}$ & 179 & 321 \\
\hline
\end{tabular}


Table 1 showed that there were three questions related to finding main idea aspect. Then there were twenty four questions realted to the finding of specific information, three questions for inference, and ten questions realted to reference/vocabulary. In specifically, there were 109 incorrect answers of finding main idea, then there were 750 incorrect answers for finding specific infromation. There were 101 incorrect answers related to inference and 321 incorrect answers for vocabulary/reference. There were three questions related to finding main idea, there were fourteen questions related to finding speciffic information, three questions for inference, ten questions for reference/vocabulary. Since this research focused on the students' problems in answering reading questions, the researcher only concerned on the data of incorrect answer. Therefore, to know the students' dominant problems in reading comprehension, see table 3.

Table 2 Students' Problems in Reading Descriptive

\begin{tabular}{|l|l|c|c|}
\hline No & Aspect of Reading & Incorect Answer & Percentage \\
\hline 1 & Finding main idea & 109 & $72,66 \%$ \\
\hline 2 & Finding specific information & 750 & $62,50 \%$ \\
\hline 3 & Inference & 101 & $67,33 \%$ \\
\hline 4 & Vocabulary & 321 & $64,20 \%$ \\
\hline
\end{tabular}

Here are some examples of questions used in this research. Question 1 is finding main idea, question 2 is finding specific information, question 3 is making inference, and question 4 is vocabulary.

1. What does the text tell us about?
A. The backpack's material.
B. The parts of the backpack.
C. The writer's new backpack.
D. The writer's favourite colour.

2. How many parts does the backpack have?
A. One part.
B. Two parts.
C. Four parts.
D. Three parts. 
15. Which statement is TRUE according to the text?
A. Arkarr is a polite boy.
B. The writer wears glasses.
C. The writer does not like playing PlayStation.
D. Arkan always plays PlayStation in the evening.

\section{What does the word "pricey" mean?}
A. Cheap.
B. Expensive.
C. Reasonable.
D. Economical.

Based on the table 2, it can be seen that there were $72,66 \%$ of students are lack of finding main idea, there were $62,50 \%$ of students lack of finding specific information, moreover there were $67,33 \%$ of students lack of inference, and $64,20 \%$ were lack of vocabulary.

\section{Open Ended Questionnaire Result}

Besides the test, the researcher also used open ended questionnaire as the intrument of this research to find out the data about the factors influenced the students' constaint in reading comprehension. The researcher asked some questions related to this research. The interview guideline was arranged based on theory of reading constraints from Harris and Smith (1986) and theory of aspects of reading comprehension from Mc Whorter (2012). The result was as follows.

\section{Students' Reasons of Lack in Finding Main Idea}

From 20 students, there were seventy five percent of students answered that they were lack of finding main idea while answering descriptive questions because finding main idea is rather complicated, they need to read the text repeatly to find the main idea. Moreover, the students also must understand all the contents of the text to identify the main idea. In addition, two students answered that when they answer the finding main idea question, they have to observe the characteristics and structure of the text first.

2. Students' Reasons of Lack in Identifying Specific Information

There were more than fifty percent of students answered that they got problem in identifying specific information because they need to read from the beginning to finish this description so that they can get the information and answer the questions given. Rest of students also answered that they need to understand the whole content of the text. 


\section{Students' Reasons of Lack in Making Inference}

There were more than half students answered that they got problems in making inference because to find inferences they must know the text well and clearly. Moreover, to determine the reference the students must be more careful in reading the text, and if they are not careful, they must read it repeatedly until they find the correct answer.

4. Students' Reasons of lack in understanding Vocabulary

Mostly the students answered that they have limited vocabulary while reading therefore they felt difficult to answer the questions. There are some words that they find difficult to understand and they have never met. They answered that there are some words which are not familiar to them. The words that they have never used before. The students also answered this is almost similar to difficult vocabulary.

Based on the result above, there were four causes of students' problems in answering reading comprehension questions of descriptive text in the "Mandiri" textbook published by Erlangga at SMPN 1 Kepahiang, they were; (1) finding main idea is rather complicated, the students need to read the text repeatly to find the main idea; (2) the students need to read from the beginning to finish this description so that they can get the information and answer the questions given; (3) to find inferences they must know the text well and clearly; (4) There are some words that they find difficult to understand and they have never met. They answered that there are some words which are not familiar to them.

\section{Discussion}

The Students' Problems in Answering Reading Comprehension Questions of Descriptive Text in the "Mandiri" Textbook Published by Erlangga at SMPN 1 Kepahiang.

The finding of this research showed that the students' problems in answering reading comprehension questions of descriptive text in the "Mandiri" textbook published by Erlangga at SMPN 1 Kepahiang were finding main idea, identifying specific information, inference, and vocabulary. Based on the result, there were seventy two percent of students are lack of finding main idea, there were sixty two percent of students lack of finding specific information, moreover there were sixty seven percent of students lack of inference, and sixty four percent were lack of vocabulary. Therefore, the dominant one was lack of finding main idea and the less one was lack of finding specific information.

Reading comprehension problems have been a popular issue in EFL teaching-learning settings for a long time. Numerous studies have shown that most EFL students often have 
difficulties in comprehending English texts. Vogel (1998) as cited in Chen and Chen (2015) has said that about $52 \%$ of adults with L2 reading comprehension problems had difficulties in learning a foreign language. In this sense, there are a number of reading problems which may be encountered by EFL students. First, they are probably not keen on reading L2 literature because they have to work hard to comprehend it. Second, studies mention several common problems in the EFL reading classroom such as insufficient vocabulary, problems understanding linguistic complexity including lexical and syntactic knowledge, language inaccessibility, poor reading skills and lack of schemata (Grabe, 1991).

Learning a new language cannot be separated from vocabulary. Meaning that in learning a new language people have to know its vocabulary. Vocabulary can be defined in various ways. Experts have proposed some terms about vocabulary. According to Richards and Renandya (2002: 255), vocabulary is a core component of language proficiency and provides much of the basis for how learners speak, listen, read and write. Without an extensive vocabulary and strategies for acquiring new vocabulary, learners often achieve their potential and may be discouraged from making use of language learning opportunities around them such as listening to the radio, listening to the native speaker, using language in different context, reading or watching television.

\section{The Students' Reasons Related to the Problems in Answering Reading Comprehension Questions of Descriptive Text in the "Mandiri" Textbook Published by Erlangga at SMPN 1 Kepahiang}

Another finding showed that there were four causes of students' problems in answering reading comprehension questions of descriptive text in the "Mandiri" textbook published by Erlangga at SMPN 1 Kepahiang, they were; (1) finding main idea is rather complicated, the students need to read the text repeatly to find the main idea; (2) the students need to read from the beginning to finish this description so that they can get the information and answer the questions given; (3) to find inferences they must know the text well and clearly; (4) There are some words that they find difficult to understand and they have never met. They answered that there are some words which are not familiar to them.

The students' problems were also caused by some aspects of reading comprehension according to Whorter (2012). As Whorther (2012) stated that the aspects of reading comprehension were finding main idea, identifying specific information, reference, inference, and vocabulary. This research found that the students were lack in finding main idea. The main idea is the statement made about the topic which is supported by detail. 
According to Dararat (2012:11) to find the main idea of paragraph, a reader must find what common element the sentences shared. The finding of this research also showed that identifying supporting infromation or specific information becomes the constraint. Supporting sentence or specific information develops the topic sentence by giving definitions, examples, facts, an incidents, comparison, analogy, cause and effect and quotation. According to Hood and Soloman in Dararat (2012:11), reading for detail is skill that a reader can get all information of the text thoroughly. Readers need to be more careful and slower assuring that they have correctly understood the message.

Moreover, lack of determining inference also be the constraint in reading comprhension. In relation to make inferences, Kathleen (2011: 31) states that an inference is an educational guess or prediction about something unknown based on available facts and information. It is the logical connection that the reader draw between his observes or unknown and what he does not know. According to Moreillon in Dewi (2013:23) inference requires that each reader construct a meaning that makes the text a reflection of her experience. Another constraints were lack of vocabulary and reference. Vocabulary is the stock of word used by the people or even person.

The result of this research was similar to the theory from Harris and Smith (1986) who divided three major factors of students' constraints in reading comprehension. As the finding of this research which revealed that there were three factors which causes of students' constraints in reading comprehension. The first was internal factor. This factor consisted of background experience, language abilities, thinking ability, affection (interest, motivation, attitudes, beliefs, and feelings), and reading purpose factors.It was similar to Harris and Smith (1986) theory who stated that the internal factors can affect a reader to comprehend a text.

The second factor found in this research was the external to the reader that is clarity of the text. The text should be in accordance with the reader's proficiency level, that is, the text is not too difficult or complicated to read. The appropriateness of the overall structure created by the writer and his/her ability to reveal that structure to the reader can facilitate or impede comprehension. The finding confirmed theory from Harris and Smith (1986) theory who also mentioned that external factor as major factor of constraints in reading comprehension.

Furthermore, this research finding was also confirmed the result from some previous studies. First Mauli (2014), she found that there were six problems faced by students in finding main idea,that is: 1). there were 19 students who lack of the students interest, 2). there were 25 students who lack of vocabulary knowledge, 3). there were 17 students who had 
problem in identifying the main idea of the passage with very long sentence, 4). there were 19 students who had poor reading strategy, 5). there were 18 students who had problem in sentence pattern (grammatical confusion), 6). there were 21 students who ignore paragraph components. It was similar to the finding of this research.

Another study was conducted by Zuhra (2014) who found out the most difficult types of reading comprehension questions faced by students in reading tests and why they faced these difficulties in the national examination. From the interview, she found that the students had an inadequate knowledge of vocabulary and sentence structure but they lacked knowledge about different types of reading comprehension questions. It can be concluded that there were some factors that caused difficulties for the students in answering these tests. This present research also found that vocabulary becomes one of problems in reading comprehension.

\section{Conclusion and Suggestion}

Based on the result in the previous chapter, it can be concluded that: (1) The students' problems in answering reading comprehension questions of descriptive text in the "Mandiri" textbook published by Erlangga at SMPN 1 Kepahiang were lack of finding main idea, lack of identifying specific information, lack of determining inference, and lack of vocabulary. (2) There were four reasons of students' problems in answering reading comprehension questions of descriptive text in the "Mandiri" textbook published by Erlangga at SMPN 1 Kepahiang, they were; (1) finding main idea is rather complicated, the students need to read the text repeatly to find the main idea; (2) the students need to read from the beginning to finish this description so that they can get the information and answer the questions given; (3) to find inferences they must know the text well and clearly; (4) There are some words that they find difficult to understand and they have never met. They answered that there are some words which are not familiar to them.

Based on the findings and conclusions above, there were some suggestions which might be useful for teaching and learning activity in reading comprehension. It is suggested for the students to learn reading repeatly to overcome the problems found in reading comprehension, for example the lack of vocabulary which became the most dominant problem in answering reading descriptive text questions. By overcoming the problems found in this research, the students have better proficiency in reading comprehension. Moreover, the teacher can also give the students ways, such as cognitive strategy, metacognitive strategy, 
think aloud strategy or other reading strategies used in reading comprehension in order to overcome their reading constraints and also motivate the students to be active reader.

\section{References}

Adeani, I. S., Febriani, R. B., \& Syafryadin, S. Using GIBBS reflective cycle in making reflections of literary analysis. Indonesian EFL Journal (IEFLJ). 6(2), 139-148.

Alderson, J. C. (2000). Assessing reading. Cambridge: Cambridge University Press

Brown, H.D. (2007). Teaching by principles: an interactive approach to language pedagogy. Third Edition. White Plains: Pearson Longman.

Chen, S. C., \& Chen, K. T. (2015). The Use of EFL Reading Strategies among High School Students in Taiwan. The Reading Matrix, 15(2), 156-166

Dalman, S. (2013). Keterampilan membaca. Jakarta: Raja Grafindo Persada.

Dararat, P. (2012). Vocabulary instruction for students with learning disabilities: A review of the research. Learning Disabilities Quarterly, 26, 117-128.

Davin, R. \& Van Staden, C. (2005). The reception year: learning through play. Heinemann: S.A.

Day, R. and Bamfod. (1998). New ways in teaching reading.teacher of English speaker of other languages.inc (tesol1999).

Decarrico, J. S. (2001). Vocabulary learning and teaching. Celce-Murcia, M. (ed.). Teaching English as a Second or Foreign Language, pp. 285-299. Boston: Heinle \& Heinle.

Dewi, F. (2013). The effects of long-term vocabulary instruction on reading comprehension: A replication. Journal of Reading Behavior, 15, 3-18.

Dhillon, B. P. S., Herman, H., \& Syafryadin, S. (2020). The Effect of Skimming Method to Improve Students' Ability in Reading Comprehension on Narrative Text. Linguists: Journal Of Linguistics and Language Teaching, 6(1), 77-88.

Duffy, G. Roehler, L., Meloth, M., Vavrus, L., Book, C., Putnam, J., \& Wesselman, R. (1986). The relationship between explicit verbal explanations during reading skill instruction and student awareness and achievement: A study of reading teacher effects. Reading Research Quarterly, 21, 237-252.

Febriani, R. B. Satinem., Nurnaningsih., Haryani., Syafryadin, Noermanzah.(2020). Conveying an author's intention to efl readers: The meaning of "The Road Not Taken" by Robert Frost. International Journal of Innovation, Creativity and Change (IJICC), 13(4), 172.

Grabe. W. (2002). Reading in second language moving from theory to practice. New York. Cambridge University Press. 
Handayani, S., Youlia, L., Febriani, R.B., Syafryadin, S. (2020). The use of digital literature in teaching reading narrative text. Journal Of English Teaching, Applied Linguistics And Literatures (JETALL). 3(2), 65-74.

Harmer. J.(2002). How to teach English: an introduction to the practice of English language teaching. Pearson education limited

Harris, L. A., \& Smith, C. B. (1986). Reading instruction: Diagnostic teaching in the classroom. New York: Macmillan

Hiebert, E. H. (2005). Teaching and learning vocabulary: Perspectives and persistent issues. Mahwah, NJ: Erlbaum

Hinkel, E. (2006). Current perspectives on teaching the four skills. TESOL Quarterly, 40(1), 109- 131. [online]. http://www.jstor.org.ezproxy.jyu.fi/stable/40264513

Hornby, AS. (1987). Oxford advanced learner's dictionary of current English. Oxford University Press. New York.

Kathleen. (2011). Reading skills for college students. Engelwood Clipps, New Jersey: Prentice Hall, Inc

Kuswidyastutik. (2013). Identifikasi kesulitan belajar matematika siswa kelas IV SDN Kedungringin 1. Surabaya: UIN Sunan Ampel.

Linnan et al. (2007). Practical meta-analysis. thousand oaks. CA: Sage Publications.

Mark.\& Anderson, K. (1998). Text types in English. 3.2.1. ed. South Yarra: Mac Milan Education Australia PTY LTD

Martin, D.S. (2003). Cognition, education and deafness: direction for research. United States of America: Gallauded University Press.

Martina, F., Syafryadin, S., \& Utama, J. A. (2020). The Practice of extensive reading among EFL learners in tertiary level. Yavana Bhasha: Journal of English Language Education, 3(2), 56-72.

Martina, F., Syafryadin, S., Rakhmanina, L., \& Juwita, S. (2020). The effect of time constraint on student reading comprehension test performance in narrative text. Journal of Languages and Language Teaching, 8(3), 323-329.

Mauli. (2014). An analysis of students' problems in finding main idea of reading text at the second grade of Mtsn 1 Kotabumi.

McCarthy, M. J. (1990). Some vocabulary patterns in conversation. In R. A. Carter and M. J.

Mc Whorter. (2012). Guide to collage reading. Toronto: Little, Brown and Company 
Miles,M.B., Huberman,A.M., \& Saldana, J. (2004). Qualitative data analysis, A methods sourcebook, Edition 3. USA: Sage Publications. Terjemahan Tjetjep Rohindi Rohidi, UI-Press.

Milkukecy, B.S. (2011). Teaching reading in a second language. Rusia: Pearson Education.Inc

Montgomery, Judy K. (2007). MAVA-Montgomery assessment of vocabulary acquisition. Greenville, South Carolina: Super Duper Publications, Inc.

Nunan, D. (2003). Practical English language teaching. New York:The McGraw-Hill Companies,Inc.

Wibowo, Y., Syafrizal, S., \& Syafryadin, S. (2020). An Analysis of English Teachers' Strategies in Teaching Reading Comprehension. JALL (Journal of Applied Linguistics and Literacy), 4(1), 20-27. 